\title{
Association of CYP19A1 rs743572 Polymorphism with Breast Cancer Risk Factor in Iraqi Women- Case Control Study
}

\author{
Iman AL-Bedairy $^{{ }^{*}} \quad$ Abdul-Hussein Al Faisal ${ }^{1,2}$ \\ 1.Ph.D. student at Genetic Engineering and Biotechnology Institute / University of Baghdad, Iraq. \\ 2. Prof. at Genetic Engineering and Biotechnology Institute / University of Baghdad, Iraq.
}

\begin{abstract}
Breast cancer (BC) is the most common cancer and the second cause of mortality in women all around the world. It is caused by several factors including genetic determinants, so that both genetic susceptibility factors and environmental factors are involved in the etiology. Significance of genes functioning in steroid hormone synthesis and metabolism are well established in breast cancer susceptibility. Polymorphisms of genes encoding enzymes involved in estrogen biosynthesis pathway and in the metabolic activation of pro-carcinogens to genotoxic intermediates, such as cytochrome P450C17 (CYP17) was closely examined in this women-based case control study of Iraqi women aged range (27-91). The associations between selected single nucleotide polymorphisms (SNPs) in the CYP17 gene and breast cancer for 105 women with breast cancer and 120disease- free controls were evaluated. Restriction fragment length polymorphism (RFLP) technique was used with MspA1 digested enzyme for the PCR products. There was no significant $\mathrm{C} \rightarrow \mathrm{T}$ (rs743572) CYP17 associated with breast cancer in the Iraqi women studied.
\end{abstract}

Keywords: breast cancer, CYP17, P450, SNPs.

DOI: $10.7176 / \mathrm{JMPB} / 66-05$

Publication date:June 30th 2020

\section{Introduction}

Breast cancer $(\mathrm{BC})$, is a disorder of cell growth. $\mathrm{BC}$ is a dynamic population of abnormal somatic cells evolving through natural selection [1] (Fortunato at el. 2017). It is the most frequent malignant neoplasm among female worldwide, accounts for approximate $25 \%$ of women malignant tumor. It is reported that 1.67 million people were diagnosed for BC every year; therefore it has become a serious health issue, especially in the developing countries [2] (Theodoratou et al.; 2018). The risk of breast cancer is related to genetic, environmental, and lifestyle factors that influence the level of exposure to estrogens and other sex hormones [3-5] (Feigelson et al., 1996, Lichtenstein et al., 2000, Bhatia, 2015). It is well established that the lifetime presence of the estrogen in the blood is one of the important risk factors for breast cancer, and this is in consistence with the low incidence of the breast cancer in males due to their lower estrogen levels and lower breast tissue volume [6] (Germain, 2011). Furthermore, there is a plethora of evidence suggesting the positive role of cell surface receptors of estrogen and progesterone in tumorigenesis $[7,8]$. Several genes have been found to be involved in synthesis, function, metabolism and secretion of the steroid hormones. The most important of them is the P450 family. Among genes of this family, CYP17, CYP19 and CYP1A1 have important functions in synthesis, metabolism and maintaining the levels of the androgen and estrogen hormones, located on10q24.3, 15q21.2 and 15.q24.1 respectively [13] (Bugano et al., 2008). Much interest has long been focused on cytochrome P450c17 $\alpha$ (CYP17) and glutathione S-transferase 1 (GSTP1) genes, encoding enzymes involved in estrogen biosynthesis and metabolism [14] which encodes steroid (17-alphahydroxylase) also known as a steroid 17-alpha-monooxygenase. It performs both 17-alpha-hydroxylase and 17, 20 -lyase activity. Functions of this enzyme allow the adrenal glands and gonads to synthesize both 17-alphahydroxylated glucocorticoids (via 17-alpha-hydroxylase activity) and sex steroids (via 17, 20-lyase activity)[9-12] or in environmental carcinogens detoxification and exo- and endogenous xenobiotic transformation [15], respectively. Several polymorphisms in many different genes have been claimed to be associated with the risk of BC. Some studies have confirmed a link between CYP17 [16-20] gene polymorphisms and the risk of BC, Hence, the clinical relevance of these polymorphic genes remains to be fully elucidated and needs further investigation [21]. In view of strong evidence implicating the importance of CYP17A1 in androgen metabolic pathways, the present study aimed at genotyping $-34 \mathrm{~T}>\mathrm{C}$ (rs 743572) of CYP17A1. As of yet, no study has been conducted to see association of this SNP with breast cancer in Iraq. This study will help in generating baseline data.

\section{Material and Methods \\ 1. Patients}

The study protocol followed the guidelines of our local ethics committee and the investigation was conducted with the ethical requirements defined in the Iraq. All patients gave their informed consent to participate in the study. The current study include 105 samples ( 30 fresh tissue +75 blood) of Iraqi women with breast cancer ER+ and 120 (30 fresh tissue +90 blood samples) healthy women as a control. Iraqi women with a clinical and histological diagnosis of breast cancer (BC) were enrolled in this study between June to July 2019 from the Middle Euphrates 
cancer center, Najaf and medical city/Baghdad, Iraq.

\section{DNA Extraction and genotyping}

Genomic DNA was extracted from whole fresh blood, using gSYNC DNA Extraction Kit (Geneaid, Taiwan) and Thermo Scientific GeneJET Genomic DNA Purification Kit (ThermoFisher, USA) for fresh tissue samples after preserved the samples in RNAlater ${ }^{\circledR}$ Tissue Collection: RNA Stabilization Solution (ThermoFisher, USA) in 80C. The nucleotide sequence of primers is using primers (sense, 5'- CATTCGCACTCTGGAGTC-3, antisense, 5-AGGCTCTTGGGGTACTTG-3). PCR amplification of rs743572 (-34T $>$ C) was carried after optimization of temperature annealing for different degree $(51,53,55,57,59)$ to choose the perfect temperature annealing for this specific primer, with this conditions: $95 \mathrm{C}$ for $5 \mathrm{~min}, 9530 \mathrm{sec}, 55 \mathrm{C}$ for $1 \mathrm{~min}, 72$ for $30 \mathrm{sec}$ and $72 \mathrm{C}$ for $10 \mathrm{~min}$. After amplification, the PCR products were digested with the restriction endonuclease MspAI for 3 hours then subjected to electrophoresis through a 3\% agarose gel, and visualized by staining the gel with SAFE Stain. Different genotypes could then be distinguished based on the size of the digested fragments. A single 414-bp product defined the T homozygotes; 414-, 290-, and 124-bp products defined the TC heterozygotes; and 290-bp and 124-bp products defined the $\mathrm{C}$ homozygotes.

\section{Results}

The current study included 105 breast cancer patients. Among them 93.33\% were married, 23.8\% were with family history either in the 1 st or 2 nd degree, $93.33 \%$ with ductal carcinoma, $73.33 \%$ in grade II and $52.38 \%$ with left lateral breast carcinoma. The medium patients age was 50 years with rang between 27-91years.

Table (1): Main tumor Clinicopathological data in the patients with breast cancer

\begin{tabular}{|l|l|l|}
\hline Clinic pathological Features & No (\%) & P-value \\
\hline Age (years) & 50 & \\
Mean & 27 & --- \\
Minimum & 91 & \\
Maximum & & \\
\hline Family history & $25(23.8 \%)$ & $0.0001 * *$ \\
Yes & $80(76.2 \%)$ & \\
No & & \\
\hline Marital Status & $98(93.33 \%)$ & $0.0001 * *$ \\
Married & $7(6.67 \%)$ & \\
Non- Married & & \\
\hline Breast Type & $98(93.33 \%)$ & $0.0001 * *$ \\
Ductal & $7(6.67 \%)$ & \\
Lobular & & \\
\hline Grade & $77(73.33 \%)$ & $0.0001 * *$ \\
II & $28(26.67 \%)$ & \\
III & \multicolumn{2}{|l|}{} \\
\hline Location & $50(47.61 \%)$ & $0.0981 \mathrm{NS}$ \\
Lateral, right & $55(52.38 \%)$ & \\
Lateral, left & ** (P $\leq 0.01)$, NS: Non-Significant. & \\
\hline
\end{tabular}

The purified genome DNA of the 105 tumor case and 120 control DNA samples submerge to the PCR process to be ready to the next step of restriction fragment length polymorphism (RFLP) with MspA1 digested enzyme ( Figures 1,2). Then the PCR products were analyzed by $2 \%$ agarose gel electrophoresis. The pair of primers amplified was expected to produce a size of $414 \mathrm{bp}$. 
Figure (1): CYP17 annealing optimization separated at 414 bp on $2 \%$ agarose gel electrophoresis M: 100 BP ladder, C: control and different temperature degrees

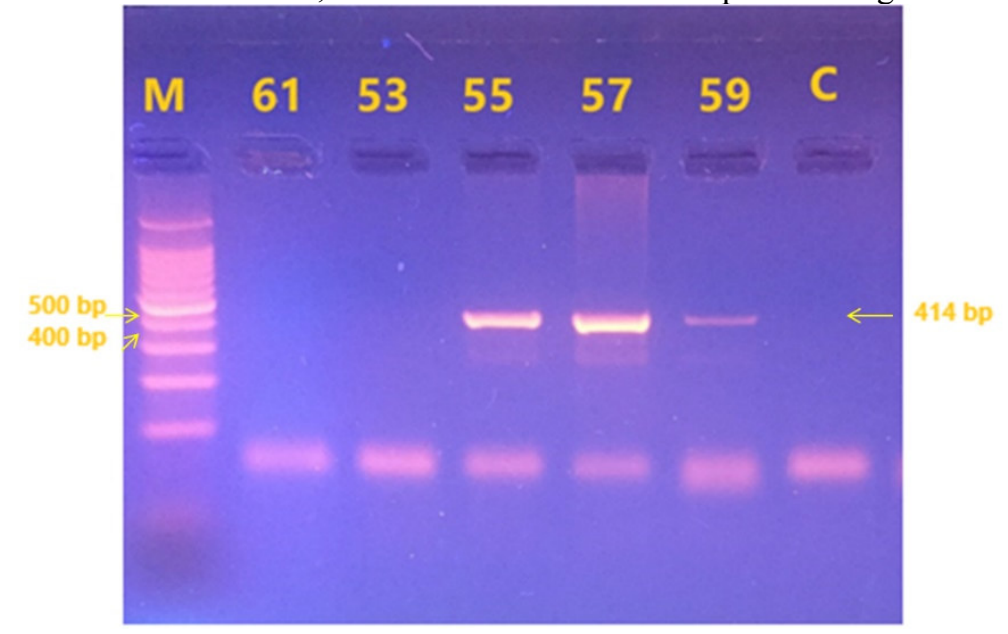

Figure (2): CYP17 products separated at 414 bp on 2\% agarose gel electrophoresis M: 100 bp ladder and (1-8) CYP17 gene product

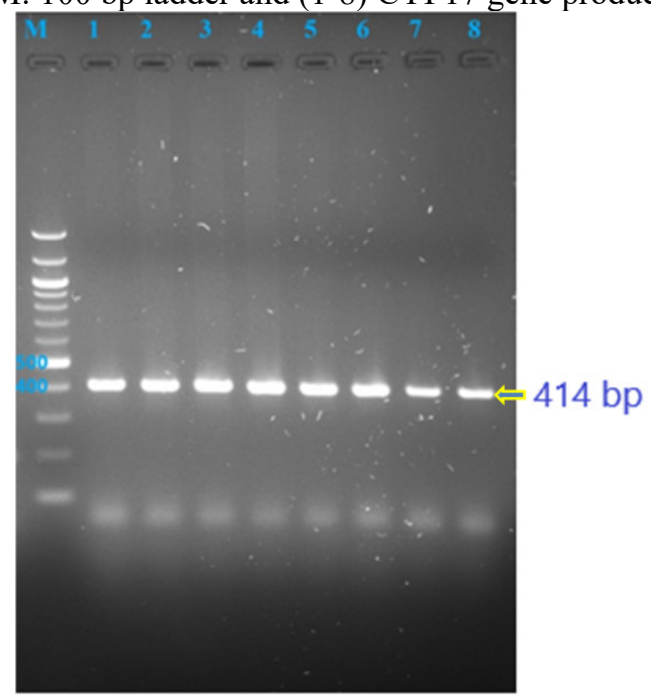

\section{Genotyping analysis}

The allele of gene CYP17 that has $\mathrm{C}$ instead of $\mathrm{T}$ at $-34 \mathrm{bp}$ was designated by the researchers who discovered this base pair substitution as: (A2) allele and the un-mutated allele with $\mathrm{T}$ at $-34 \mathrm{bp}$ were designated as a (A1) allele of CYP17(Carey, et al.; 1994 and Diamanti-Kandarakis, et al.; 1999).

\section{A: Genotyping analysis in the fresh tissue samples}

The variation of genotype of (rs743572) CYP17 MspA1 in the fresh tissue samples (figures (3) as a following (Table 2): TT (15/30) 50\%, TC (7/30) 23.33\% and CC (8/30) 26.66\% while in the control tissue samples were: TT (9/30) $30 \%$, TC (15/30) $50 \%$ and CC (6/30) $20 \%$. 
Figure (3): CYP17 MspA1 digested products for fresh tissue samples separated on 3\% agarose gel electrophoresis

Lane1(M) 100bp ladder; Lane 3 \& 6 Homozygous A1 genotype (A1/A1); Lane 2, 4, 7 \& 8 Heterozygous genotype (A1/A2); Lane 5 Homozygous A2 genotype (A2/A2).

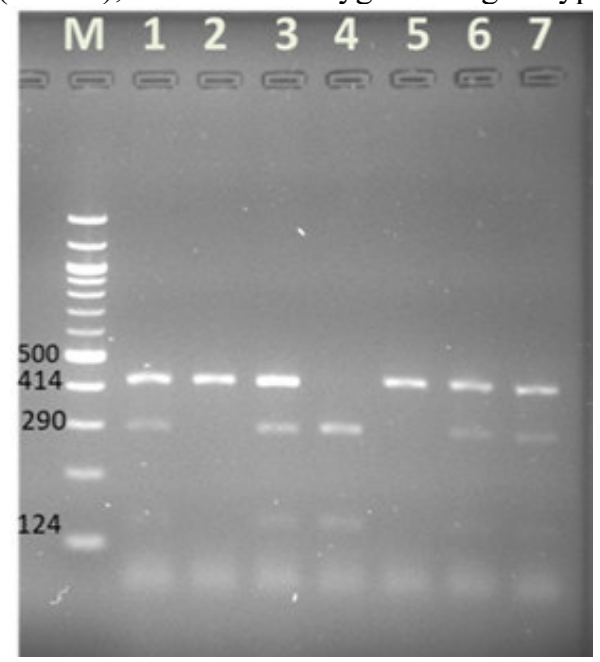

Table (2): Tumor Tissue sample recurrence for CYP17 alleles in Iraqi women with breast cancer and control

\begin{tabular}{|c|c|c|c|c|}
\hline Genotype & $\begin{array}{l}\text { Cases } \\
\text { No. }(\%)\end{array}$ & $\begin{array}{l}\text { Control } \\
\text { No. }(\%)\end{array}$ & P-value & O.R. (C.I.) \\
\hline (A1A1) TT & $15(50.00 \%)$ & $9(30.00 \%)$ & $0.0073 * *$ & $1.204(0.76-1.52)$ \\
\hline (A1A2) TC & $7(23.33 \%)$ & $15(50.00 \%)$ & $0.0066 * *$ & $1.255(0.81-1.56)$ \\
\hline$(\mathrm{A2A2}) \mathrm{CC}$ & $8(26.67 \%)$ & $6(20.00 \%)$ & $0.193 \mathrm{NS}$ & $0.778(0.54-107)$ \\
\hline Total & $30(100 \%)$ & $30(100 \%)$ & -- & -- \\
\hline Allele & \multicolumn{4}{|l|}{ Frequency } \\
\hline (A1) $\mathrm{T}$ & 0.62 & 0.55 & -- & -- \\
\hline (A2) $\mathrm{C}$ & 0.38 & 0.45 & -- & -- \\
\hline
\end{tabular}

\section{B: Genotyping analysis in the Blood samples}

The variation of genotype of (rs743572) CYP17 MspA1 in the blood samples (Figure 4) were as a following (Table $3)$ : the patients frequency were TT (34/75) 45.33, TC (28/75) $37.33 \%$ and CC (13/75) $17.33 \%$ while the control frequency were TT (37/90) 41.11\%, TC (37/90) $41.11 \%$ and CC (16/90) $17.77 \%$.

Table (3): Tumor blood samples recurrence for CYP17 alleles in Iraqi women with breast cancer and control.

\begin{tabular}{|l|l|l|l|l|}
\hline Genotype & $\begin{array}{l}\text { Cases } \\
\text { No. }(\%)\end{array}$ & $\begin{array}{l}\text { Control } \\
\text { No. }(\%)\end{array}$ & P-value & O.R. (C.I.) \\
\hline TT & $34(4335 \%)$ & $37(41.11 \%)$ & $0.469 \mathrm{NS}$ & $0.307(0.28-0.51)$ \\
\hline TC & $28(37.33 \%)$ & $37(41.11 \%)$ & $0.475 \mathrm{NS}$ & $0.281(0.25-0.48)$ \\
\hline CC & $13(17.33 \%)$ & $16(17.78 \%)$ & $0.892 \mathrm{NS}$ & $0.166(0.09-0.33)$ \\
\hline Total & $75(100 \%)$ & $90(100 \%)$ & -- & -- \\
\hline Allele & Frequency & 0.62 & -- & - \\
\hline T & 0.64 & 0.38 & -- & - \\
\hline C & 0.36 & \multicolumn{2}{|l|}{} \\
\hline NS: Non-Significant.
\end{tabular}


Figure (4): CYP17 MspA1 digested products for blood samples separated on 3\% agarose gel electrophoresis Lane (M) 100bp ladder; Lane 9, 10, 14 \& 15 Homozygous T genotype (TT); Lane 1, 2, 3, 4, 6, 7, 8, $11 \& 13$ Heterozygous genotype (TC); Lane 5 and 12 Homozygous A2 genotype (CC).

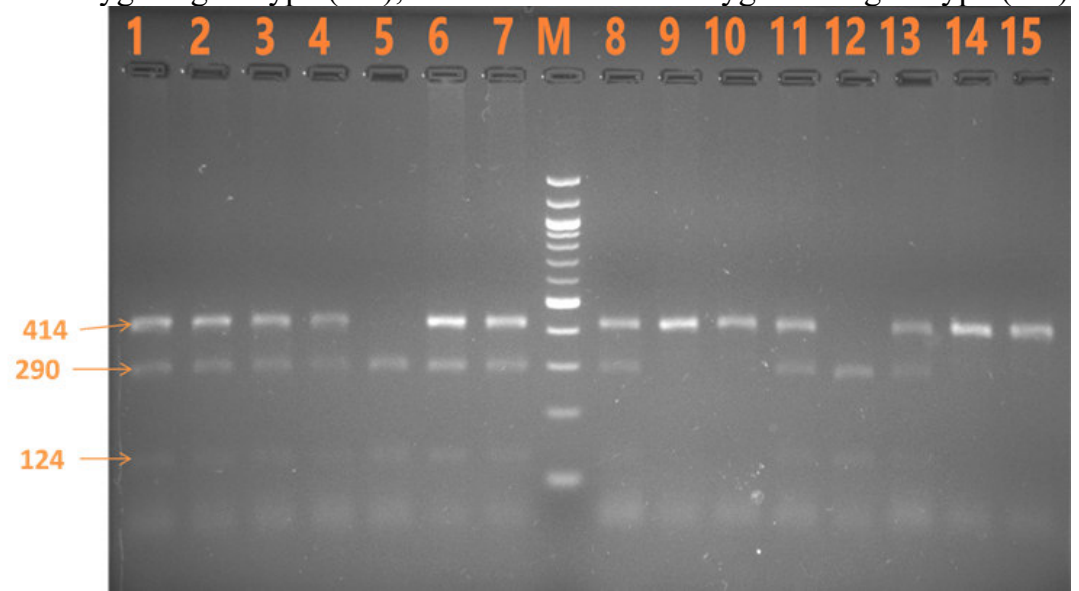

The total variation of genotype of (rs743572) CYP17 MspA1 for both fresh tissue and blood samples (105 cases +120 control) as a following (Table 4): the frequency of TT (414 bp) allele in the patients was 49 (46.66\%), TC (414, 290 and 124 bp) 35 (33.33\%) and CC (290 and 124 bp) 21 (20\%) while in the control was: TT 46 $(38.33 \%)$, TC $52(43.33 \%)$ and CC $22(18.33 \%)$.

Table (4): Total tumor samples recurrence for CYP17 alleles in Iraqi women with breast cancer and control

\begin{tabular}{|l|l|l|l|l|}
\hline Genotype & $\begin{array}{l}\text { Cases } \\
\text { No. (\%) }\end{array}$ & $\begin{array}{l}\text { Control } \\
\text { No. (\%) }\end{array}$ & P-value & O.R. (C.I.) \\
\hline TT & $49(46.67 \%)$ & $46(38.33 \%)$ & $0.0966 \mathrm{NS}$ & $0.179(0.094-0.29)$ \\
\hline TC & $35(33.33 \%)$ & $52(43.33 \%)$ & $0.0472 *$ & $0.772(0.58-1.02)$ \\
\hline CC & $21(20.00 \%)$ & $22(18.33 \%)$ & $0.664 \mathrm{NS}$ & $0.471(0.32-0.61)$ \\
\hline Total & $105(100 \%)$ & $120(100 \%)$ & -- & -- \\
\hline Allele & Frequency & -- & - \\
\hline T & 0.63 & 0.60 & -- & - \\
\hline C & 0.37 & 0.40 & \\
\hline
\end{tabular}

\section{Discussion}

The statistical analysis of (Table1) data showed a significant $\mathrm{P} \leq 0.01$ between studied clincopathological features except in location of breast cancer which revealed that no statistical significance between cancer if was left or right breast.

The difference in the frequency of the homozygous A1A1 and A1A2 genotype between the 30 fresh tissue affected women with breast cancer with the 30 controls was statistically significant by P-value 0.0073 and 0.0066 with O.R. (C.I.) 1.204 and 1.255 respectively $(\mathrm{P} \leq 0.01)$, while no significant with the A2A2 allele frequency.

In the blood samples, there is no significant in the frequency of the homozygous A1A1, A2A2 and A1A2 genotype allele between the 75 affected women with breast cancer and 90 controls. The final screening of the samples investigated the frequency of $\mathrm{T} \rightarrow \mathrm{C}$ substitution at $-34 \mathrm{bp}$ from the initiation site of translation of gene CYP17 polymorphic (A2 allele of gene CYP17) in Iraqi women patients presenting with breast cancer ER+ and in matched controls, there was statistically significant by P-value 0.0472 with O.R. (C.I.) 0.772 (P $\leq 0.05)$ for Heterozygous genotyping (A1A2) TC in control samples. There was no significant association with tumor cases.

A study in Iraq that deals with CYP17 frequency with endometriosis disease, they observed significant associations between CYP17 SNPs (rs743572) and genotypes of Iraqi women with endometriosis disease [21] (AlRubae, et al., 2017). While another Iraqi study done by [22] Mohammed et al., (2015) suggested that the (T/C) polymorphism in the CYP 17 gene was not associated with PCOS (Poly cystic ovary) in Iraqi women.

The results of this study corroborates of a neighboring Iranian study presented by [23] (Ebrahimi et al., 2017) which examined genotype variation in the whole population. They found that: $72(35.1 \%)$ were A1/A1, $104(50.7 \%)$ were A1/A2 and 29 (14.1\%) were A2/A2. The frequency of A1 and A2 alleles in the total population was $60.48 \%$ and $39.51 \%$, respectively.

On the other hand, there are many studies in Europe that showed no significant differences detected in either the allele frequencies or the genotype distributions between the control and breast cancer patients in the British population [24] (Dunning et al., 1998), German population [25] (Verla-Tebit et al., 2005) and in Italian [20] 
(Antognelli et al., 2009). Furthermore, a recent Egyptian population study [26] (Youssef, et al., 2018) found that the A2 allele did not significantly affect the breast cancer risk. Additionally, meta-analysis studies found the association of CYP17 T-34C polymorphism with breast cancer susceptibility in the Chinese population including 27,104 cases and 34,218 controls. These studies found no significant correlation between this polymorphism and breast cancer susceptibility [27] (Sun et al. 2018) in addition to [28] Weng et al., (2019) study.

On the other hand, there were few studies which found correlation between CYP17 polymorphism and breast cancer susceptibility like India study [29] (Surekha et al., 2010) which found that: the TT genotype frequency was increased in breast cancer patients $(68.7 \%)$ when compared to controls $(55.4 \%)$. While 2018 Chinese study published by [30] Yang and his colleagues suggested that CYP17 polymorphisms may reduce the susceptibility to breast cancer in Chinese women.

\section{Conclusion}

The findings in the current study revealed that there is no significant correlation between CYP17 polymorphism and breast cancer susceptibility with allele frequency 0.63 for $\mathrm{T}$ and 0.37 for $\mathrm{C}$. The results of many studies that examined the association between MspA1 CYP17 variant and breast cancer were inconsistent. The wide variation in these studies may come from the difference in study methods and perhaps some of these studies were not population based which may be affected by selection bias. Also studies differ markedly in size number of patients and control so they varied in statistical significance.

\section{References}

1. Fortunato, A., Boddy, A., Mallo, D., Athena Aktipis, A., Maley, C.C. \& Pepper, W.J. (2017). Natural Selection in Cancer Biology: From Molecular Snowflakes to Trait Hallmarks. Cold Spring Harb Perspect Med. $7(2): 1-20$.

2. Theodoratou, E., Timofeeva, M., Li, X., Meng, X. \& Ioannidis, P.A. (2018). Nature, Nurture and cancer risks: Genetic and nutritional contributions to cancer. Annu Rev Nutr.21; 37: 293-320.

3. Feigelson, HS. \& Henderson, BE. (1996). Estrogens and breast cancer Carcinogenesis . 17:2279-2284.

4. Lichtenstein, P., Holm, N.V., Verkasalo, P.K., Iliadou, A., Kaprio, J., Koskenvuo, M. Pukkala, E. ; Skytthe, A. and Hemminki, K. (2000). Environmental and heritable factors in the causation of cancer--analyses of cohorts of twins from Sweden, Denmark, and Finland. N Engl J Med.343: 78-85.

5. Bhatia, S. (2015). Genetic Variation as a Modifier of Association between Therapeutic Exposure and Subsequent Malignant Neoplasms in Cancer Survivors. Cancer. 121(5): 648-663.

6. Germain, D.(2011). Estrogen carcinogenesis in breast cancer. Endocrinol. Metab. Clin. N. Am. 40, $473-484$.

7. Sattin, RW., Rubin, G, \& Wingo PA, et al. (1986). Oral-contraceptive use and the risk of breast cancer. The cancer and steroid hormone study of the centers for disease control and the national institute of child health and human development. N Engl J Med, 315, 405-11.

8. Farzaneh, F., Noghabaei, G., Barouti, E., Pouresmaili, F., Jamshidi, J., Fazeli, A., Taghavi, S., Emamalizadeh, B. \& Darvish, H.(2016). Analysis of CYP17, CYP19 and CYP1A1 Gene Polymorphisms in Iranian Women with Breast Cancer. Asian Pacific Journal of Cancer Prevention. 17. Cancer Control in Western Asia Special Issue, 23-26.

9. Reid, A.H., Attard, G., Barrie, E. \& de Bono, JS. (2008). CYP17 inhibition as a hormonal strategy for prostate cancer. Nat Clin Pract Urol, 5:610-620.

10. van den Akker, EL., Koper, JW., Boehmer, AL., Themmen, AP., Verhoef-Post, M., Timmerman, MA., Otten, BJ., Drop, SL. \& De Jong, FH. (2002). Differential inhibition of $17 \alpha$-hydroxylase and 17, 20-lyase activities by three novel missense CYP17 mutations identified in patients with P450c17 deficiency. $J$ Clin Endocrinol Metab, 87:5714-5721.

11. Blackburn, HL., Ellsworth, DL., Shriver, CD. \& Ellsworth, RE. (2015). Role of cytochrome P450 genes in breast cancer etiology and treatment: effects on estrogen biosynthesis, metabolism, and response to endocrine therapy. Cancer Causes Control, 26:319-332.

12. Setiawan, VW., Schumacher, FR. \& Haiman CA et al. (2007). CYP17 genetic variation and risk of breast and prostate cancer from the National Cancer Institute Breast and Prostate Cancer Cohort Consortium (BPC3). Cancer Epidemiol Biomarkers Prev, 16:2237-2246.

13. Bugano, DD., Conforti-Froes, N. \& Yamaguchi, NH. et al. (2008). Genetic polymorphisms, the metabolism of estrogens and breast cancer: a review. Eur J Gynaecol Oncol, 29, 313-20.

14. Picado-Leonard, J. \& Miller, WL. (1987). Cloning and sequence of the human gene for P450c17 (steroid 17 alpha-hydroxylase/ 17,20 lyase): similarity with the gene for P450c21. DNA. 6(5):439-48.

15. Whalen, R. \& Boyer, TD. (1998). Human glutathione S-transferases. Semin Liver Dis. 18(4):345-58.

16. Feigelson, HS., Coetzee, GA., Kolonel, LN., Ross, RK. \& Henderson, BE. (1997). A polymorphism in the CYP17 gene increases the risk of breast cancer. Cancer Res. 57(6):1063-5.

17. Feigelson, HS., McKean-Cowdin, R., Coetzee, GA., Stram, DO., Kolonel, LN. \& Henderson, BE. (2001). 
Building a multigenic model of breast cancer susceptibility: CYP17 and HSD17B1 are two important candidates. Cancer Res. 61(2):785-9.

18. Chakraborty, A., Murthy, NS., Chintamani, C., Bhatnagar, D., Mohil, RS., Sharma, PC. \& Saxena, S. (2007). CYP17 gene polymorphism and its association with high-risk north Indian breast cancer patients. J Hum Genet. 52(2):159-65.

19. Chen, Y., Gammon, MD., Teitelbaum, SL., Britton, JA., Terry, MB., Shantakumar, S., Eng, SM., Wang, Q., Gurvich, I., Neugut, AI., Santella \& RM., Ahsan, H. (2008). Estrogen-biosynthesis gene CYP17 and its interactions with reproductive, hormonal and lifestyle factors in breast cancer risk: results from the Long Island Breast Cancer Study Project. Carcinogenesis. 29(4):766-71.

20. Antognelli, C., Del Buono, C., Ludovini, V., Gori, S., Talesa, V.N., Crinò, L., Barberini, F. \& Rulli, A. (2009). CYP17, GSTP1, PON1 and GLO1 gene polymorphisms as risk factors for breast cancer: an Italian case-control study. BMC Cancer. 9:115. 1-14.

21. Al-Rubae'i H.N.S., Naji, T. S. \& Turki K. M. (2017). Common variation of the CYP17 gene in Iraqi women with endometriosis disease. Genomics Data. 11 55-59.

22. Mohammed, MB., AL-Awadi, SJ. \& Omran, MA.(2015). Association between polycystic ovary syndrome and genetic polymorphisms of CYP 17 gene in Iraqi women. Iraqi J Biotechnol. 14(2):99-110.

23. Ebrahimi, E., Sabokbar, T., Eskandarieh, S., Peyg-Hambari, V. \& Shirkoohi, R. (2017). CYP17 MspA1 Gene Polymorphism and Breast Cancer Patients According to Age of Onset in Cancer Institute of Iran. Iran J Public Health. 46( 4). 537-544.

24. Dunning, AM., Healey, CS. \& Pharoah, PD. (1998). No association between a polymorphism in the steroid metabolism gene CYP17 ad risk of breast cancer. Breast Cancer Journal. 77:2045-47.

25. Verla-Tebit, E., Wang-Gohrke, S. \& Chang-Claude. (2005). CYP17 5'-UTR MspA1 polymorphism and the risk of pre-menopausal breast cancer in a German population-based case-control study. Breast Cancer Res. 7:455-64.

26. Youssef, E.M., Albezrah, N.A., Ezzat, A.A., Sedik, W.F., Radwan, E.E., Yehia, A.E., Tash, R.E, Ahmed, M.A. \& Elbahaie, A.M. (2018). Role of Galactose Specific Lectin 3 and CYP17A1 Gene Polymorphism in Breast Cancer. Research In Cancer and Tumor. 6(1).5-12.

27. Sun, J.; Zhang, H., Gao, M., Tang, Z., Guo, D., Zhang, X., Wang, Z., Li, R., Liu, Y., Sun, W. \& Sun, X. (2018). Association between CYP17 T-34C rs743572 and breast cancer risk. Oncotarget. 9, (3) 4200-4213.

28. Weng, H., Fang, C., Geng, P., Jin, Y., Zeng, X. \& Wang, X. (2019). Role of CYP17 rs743572 Polymorphism in Benign Prostatic Hyperplasia: A Multivariate Integrated Analysis. Frontiers in Physiology. 10. (774).1-9.

29. Surekha, D., Sailaja, K. \& Rao, D.N. (2010). Association of a CYP17 gene polymorphism with development of breast cancer in India. Asian pacific J Cancer Prev.11: 1653-1657.

30. Yang, P., Wang, M., Tian, T., Feng, Y., Zheng, Y., Yang, T., Li, H., Lin, S., Xu, P., Deng, Y., Hao, Q., Li, N., Guan, F. \& Dai, Z. (2018). CYP17 polymorphisms are associated with decreased risk of breast cancer in Chinese Han women: a case-control study. Cancer Management and Research. 10. 1791-1798. 